Adam Dziadek

\title{
Themerson and Schwitters
}

DO|:10.18318/td.2015.en.2.12

\section{Milton, Themerson and Schwitters}

To begin with, a quotation:

This neglect then of rime so little is to be taken for a defect, though it may seem so perhaps to vulgar readers, that it rather is to be esteemed an example set, the first in English, of ancient liberty recovered to heroic poem from the troublesome and modern bondage of riming. ${ }^{1}$

This passage comes from John Milton's Paradise Lost, but what could such a quotation have to do with Stefan Themerson and Kurt Schwitters? What could Milton, Schwitters and Themerson possibly have in common? "Common sense" would suggest that this is a fundamentally wrong juxtaposition. But this strange juxtaposition is only partly guided by chance, while "common sense" itself, as rightly noted by Roland Barthes in Mythologies, is a thoroughly bourgeois term, and therefore, I would suggest, unworthy of being stooped to or identified with in any way. We must therefore right away

1 John Milton, Paradise Lost: The Verse, accessed August 20, 2015, http://www.bartleby.com/4/400.html

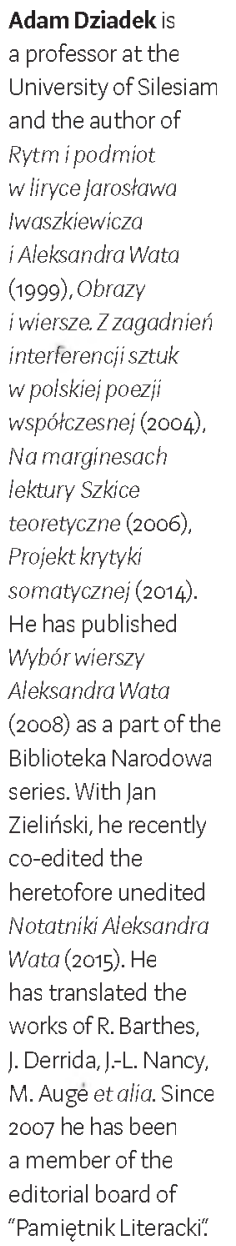 \\ Adam Dziadek is \\ University of Silesiam \\ and the author of \\ Rvtmipodmiot \\ wliryce larostawo \\ Iwaszkiewiczo \\ iAleksandraWata \\ (1999), Obrazy \\ iwiersze. Zzagadnień \\ interferenciisztuk \\ w polskiej poezil \\ wspótczesnej (2004) \\ marginesach \\ teoretyczne (2006) \\ Projekt kntyk \\ somatycznei (2014). \\ He has published \\ Wybórwierszy \\ AleksandraWata \\ (2008) as a part of the \\ Biblioteka Narodowa \\ series. With Jan \\ Zieliński, he recently \\ co-edited the \\ heretofore unedited \\ Notatniki Aleksandro \\ alated the \\ . Derrida, J.-L. Nancy, \\ M. Auge et alia. Since \\ 2007 he has been \\ a member of the \\ "Pamiętnik Literacki"
}


reject "common sense" as a concept, just as Schwitters did in Hanover and Themerson in Płock.

What, then, might these three figures have in common? A great deal, in fact. For at the beginning of the strange relationship that formed between two remarkable artists at a remarkable historical time and in a remarkable place was John Milton, who, partly by coincidence, wove their fates together. The dates of this acquaintance - very importantly, in fact - were the years 1943 to 1948 . The two artists met in remarkable circumstances, at a ceremonial sitting of the PEN Club in London held in 1943 to mark the 30 oth anniversary of the publication of Milton's Areopagitica. As Themerson recalls:

Since I first met him, whenever I hear his name, [...] it is always closely followed in my mind by another name the name of another man, and if I tell you the other name now, you may say I am committing a heresy. [...] well, the name so heretically associated in my mind with the name of Kurt Schwitters, is: John Milton. ${ }^{2}$

The two men had been invited to this special PEN Club meeting and placed alongside one another. Schwitters had grown accustomed to collecting various strange objects that he found interesting, and this occasion proved no exception. On his way to the Institut Français, where the sitting was to take place, he passed a bombed-out building, and stopped to take a piece of wire from the rubble, which he proceeded to mould into a sculpture in the course of the session. The distinguished writers gathered for the ceremony thought that an electrician or plumber must have stumbled in off the street by mistake. Yet it was they who were wrong, and Schwitters's work, titled Air and Wire Sculpture, ended up at Lord's Gallery.

Milton's Areopagitica is among the most famous texts written in defence of the word, the word rebelling against every act of censorial violence committed on works of art and literature. We began with a quotation from Paradise Lost, which also resists rhyming in poetry, against the limitations it imposes, making it a "vexation, hindrance and constraint" for poets, "the Invention of a barbarous Age, to set off wretched matter and lame Meter."

Milton's revolutionary gesture was reprised in unique fashion by Schwitters, and the freedom of expression chosen by the author of Ursonate forced him to leave Germany as it was at odds with the Nazi Ordnung. Recalling Schwitters's fate, Themerson cites Kandinsky's words: "Nothing defies

2 Stefan Themerson, Kurt Schwitters in England: 1940-1948 (London: Gaberbocchus Press, 1958), 9 . 
barbarism with such force as a new art form." ${ }^{3}$ And indeed, one must admit that the originality and unconventional nature of the word "Merz" (coined, as we may recall, on the basis of a newspaper advertisement for Kommerz und Privat Bank by chopping off the first syllable of the first word), which was used to describe Schwitters's writings, pictures and constructions, fundamentally clashed with the rules imposed on all areas of life by the System, usually hostile to art and all human artistic activity. In the case of Schwitters's work, as with many other avant-garde artists (including Themerson), the anarchic element had a strong impact, striking with full force binary oppositions such as appropriate/inappropriate, norm/deviation, judicious/crazy, and my/your. Seeking to shake up these oppositions, it countered what zoth Century philosophy calls phallogocentrism unambiguously linked to diverse forms of power. As the author of Professor Mmaa's Lecture, Themerson knew this very well (admittedly, he did not know, or ever use, the word "phallogocentrism," but I assume that he would have readily accepted it).

For Themerson, the revolutionary nature of Schwitters's work had a universal and timeless character. Themerson noticed that it retained its power from the 1920s, when it was written, through the "40s, when they met, and into the ' 6 os, when he wrote a book about it. We can add that the power enshrouded in this extraordinary work remains active to this day, continuing to act in the same way. One of the most important questions undertaken by artists of the avant-garde concerns the human condition in the modern world (questions about identity, its internal and external limitations), the question of the condition of humankind, seeking to escape from, in Raoul Hausmann's words, the chaoplasm (a term from simultangedicht, published in Merz no. 4 from July 1923). The avant-gardistes were well ahead of their era, and asked questions that remain relevant today, in the postmodern age.

\section{Themerson and His Books about Schwitters}

Themerson published several books on Schwitters, each of them a kind of homage from one artist to another. The first work on the author of Merz was Kurt Schwitters in England, published by Gaberbocchus Press in 1958 and based on a lecture given at the Gaberbocchus Common Room on 25 February 1958 (Kurt Schwitters' Last Notebook). Several years later, on 17 February 1961, Themerson delivered a lecture at the Society of Arts in Cambridge which then formed the basis of the beautiful edition Kurt Schwitters on a Time Chart, published in issue 16 of the magazine Typographica (December 1967).

3 Ibid., 14 . 
To these publications, we can also add the book Kurt Schwitters, Raoul Hausmann and the Story of PIN, published by Gaberbocchus Press in 1962. This contains the story of the friendship between the two artists, which began in 1918, as well as their poems, passages from co-authored texts, photograms and photomontages of Hausmann and Schwitters's collages. It is also the history of the friendship and joint concept of two artists with a desire to tackle the innovative idea of poetry referred to by the acronym "PIN" (which can stand for several things: Poetry is Now, Présence Inter New, Poetry Intervenes New, Present Inter Noumenal) in the form of a magazine. Their idea was conceived in 1946 only came to fruition in 1963, when Themerson's publishing house issued PIN.

In writing Kurt Schwitters in England and discussing the fortunes of the German artist, Themerson was also writing partly about himself. This happened as if in this apparently alien identity he had found himself, and as if the fortunes of these two personal autarkies overlapped and merged the similarities appear rather obvious. On the one hand, both men were avant-garde, versatile artists open to diverse means of artistic expression. Themerson created "semantic poetry," which was his own invention, with his pioneering work in the field receiving international recognition. ${ }^{5} \mathrm{He}$ also wrote novels and essays translated into many languages, and with his wife, Franciszka, was one of the most interesting makers of avant-garde film, as well as an original editor. On the other hand, both artists - albeit for different reasons - worked in a foreign country and language. Themerson left Poland for Paris with his wife in 1938, joined the Polish army with the outbreak of war and from 1942 settled in England, like many other Polish writers and artists (during and after the war London became one of the strongest centres of Polish political emigration). At this point we should make it clear that Themerson, for many reasons, did not identify with the Polish émigré communities; instead, he assumed the status of a Polish writer working in many languages abroad. Meanwhile, for Schwitters, as an avant-garde artist, there was no place in fascist Germany; it was forced emigration that led him first to Norway and then to Great Britain. And it may have been this chance affinity that inspired Themerson's peculiar fascination with Schwitters. Discussing the author of An Anna Blume, he spoke of the Dada movement, its historical, political and artistic background, but

4 Kurt Schwitters, Raoul Hausmann and the story of PIN, introduced by lasia Reichardt, designed by Anna Lovell (London: Gaberbocchus Press, 1962).

5 In La littérature définitionnelle, a passage from the book Oulipo, la litterature potentielle (Paris: Gallimard, 1973, 119) written by Raymond Queneau, Themerson, with his idea of semantic literature, was acknowledged as a precursor of the ideas of Georges Perec and Queneau himself. 
it was the individual, Schwitters himself, whom he placed in the foreground, as a unique and imitable artist. In doing so, he was complying with Schwitters's will, as, when telling Themerson the story of how the word "Merz" had arisen, the former had made it clear that "the Dada people were friends. But Merz was independent. Merz was mine. Dada was everybody's." ${ }^{\text {Themer- }}$ son also pointed to the unique situation of forced alienation in which the unknown German artist had found himself in England (during his time in the country, he managed only one exhibition, held in 1944 at Bilbo's Gallery by Herbert Read, and two "Merz recitals" at London Gallery in 1947). The reason for this alienation was not only that he was an unknown artist in England, but al so that, as a German in England in wartime, he was burdened with anathema. In the minds of ordinary Britons, a German in England during the war could only be a camouflaged Nazi, just as a non-German Jew could only be a communist - these are obvious mental stereotypes that can develop especially strongly in wartime. The problem must have been all the more serious for Schwitters as he was one of those artists who find it very hard to understand classifications based on popular opinion and refuse to yield to simplified, system-based rules of thinking. Like Themerson, he was also well aware of the ideological complications of the 2oth century and consistently tried to reject them, and it was at this time that the mental and spiritual affinities of the two artists became especially strongly visible.

This book is furnished with texts written in English, selected by Themerson from Schwitters's notebook. Here are some of them:

When I am talking about the weather

When I am talking about the weather,

I know what I am talking about.?

Ibuild my time

I build my time

In gathering flowers

And throwing out the weeds.

I build my time

In gathering fruits

And throwing out all that is bad

And old and rotten.

6 Stefan Themerson, "Kurt Schwitters on a Time Chart," Typographica, 16 (1967)

7 Ibid., 47 
This time will lead me forward

To death

And God

And Paradise. ${ }^{8}$

At firstmen were limited

At first men were limited,

limited,

limited,

Until they imited, imited, imited,

But when they imited,

imited,

imitated,

Still they remained limited,

limited,

limited.

Themerson did something similar with Kurt Schwitters on a Time Chart; placing him on the map of time, he recalled their remarkable first meeting, and that the first issue of Merz had been published in Hanover the same year (1923) as Mein Kampf in Munich. As I mentioned, Themerson's book grew out of a lecture, which the author no doubt considered an insufficient and limited format. Reading his manuscript with the final printed version of Kurt Schwitters on a Time Chart, it is easy to observe certain similarities. In fact, though, these two presentations of Schwitters are diametrically different: the latter in particular becomes an original Text, pulsating with many semantic tones. I deliberately wrote the word "Text" with a capital letter, and will now attempt to explain why in detail.

\section{The Book as a Text}

The connection of diverse systems of signs made in Themerson's books on Schwitters means that reading them could follow the path of intersemiotic

8 Ibid. 52 . 
research. ${ }^{9}$ It could, but I suspect that this would be an insufficient approach; moreover, one might go so far as to say that it would be very restrictive, and Themerson himself would be opposed to it. To determine how to read them, how they might be interpreted, we can refer to the works of Roland Barthes. He concluded, rightly, that traditional semiotics dealt with heteroclite productions (pictures, myths, stories) and attempted to construct a Model, against which every artistic production could be defined in terms of deviation. ${ }^{10}$ Adopting a semiotic mode of reading, in this case, we have to go beyond the traditional way of thinking in categories of Model, Norm, Code and Law, and instead use theological terms. The emphasis therefore needs to be placed not so much on the structure, as the structuring (the way in which it is done, how it functions), not so much on the Model as the work of the system. It is worth opting for the rejection of the hermeneutic idea of seeking the truth, some secret hidden in texts, and rather look for the actions through which these texts are structured. In this way, the work of reading can be identified with that of writing. The task of the reader of Themerson's books, which are without doubt an artistic product and at the same time an unquestionable and untypical testimony, therefore becomes writing a text on Kurt Schwitters.

Themerson also wrote many books on other outstanding artists published by Gaberbocchus Press. These include Jankel Adler. An Artist Seen from One of Many Possible Angles, which features Adler's text and drawings side by side, produced especially for the needs of this remarkable publication; a beautiful edition of Apollinaire's Lyrical Ideograms; as well as Themerson's own works Semantic Divertissements and St Francis and the Wolf of Gubbio."11 Looking carefully at these typographic works, we can state categorically that they were never about "intersemiotic games," about something that could be called a simple exchange of signs taking place between systems (here I particularly emphasise the economic value of the word "exchange"). By saying "intersemiotic games," we immediately assume that systems of meaning are distinct, whereas in Themerson's books, the stress is on their coexistence. The pages

9 Cf. e.g. Artur Pruszyński, "O grach intersemiotycznych Stefana Themersona," in Archiwum Themersonów w Polsce, eds. Adam Dziadek and Dariusz Rott (Katowice, 2003), 33-74. See also: Artur Pruszyński, Dobremaniery Stefana Themersona (Gdańsk: słowo/obraz terytoria, 2005)

10 Roland Barthes, "La peinture est-elle un langage?," in Oeurres completes, vol. 3 (Paris: Seuil, 2002), 99

11 Stefan Themerson, jankel Adler. An Artist Seen from One of Many Possible Angles. With Twelve Full Page Drawings by jankel Adler (London: Gaberbocchus Press, 1948); Stefan Themerson, Apollinaire's Lyrical Ideograms (London: Gaberbocchus Press, 1968); Stefan Themerson, Semantic Divertissements (London: Gaberbocchus Press, 1962); Stefan Themerson, St Francis and the Wolf of Gubbio (London and Amsterdam: De Harmonie, 1972). 
of these books are performative so to speak, pages of writing and/or reading, a kind of drama of meaning in which the various scenes are played out simultaneously. In their untypical and remarkable nature and through the whole intratypographical and intertextual network, they form an open text that is hostile to the System and traditional reading based on and safeguarded by this same System. They assume an active participation of readers in the creation of this text, in a way forcing them to break the conventional predictability, as demonstrated, for example, by an instruction written by hand and reprinted in red that can be found in Kurt Schwitters on a Time Chart: "This space, reader, for you to fill with whatever you consider relevant."

In terms of form, the books on Schwitters resemble a collage. Kurt Schwitters in England, alongside Themerson's unconventional text, contains photographs (e.g. of the wall of the famous third Merz Barn found in Ambleside), reproductions of Schwitters's collages, sculptures, works written in England, copies of the pages of his last notebook written in English, and a photographical record of the shape of his mouth reciting the Ursonate. This recitation seems especially significant. Incidentally, Schwitters performs it in a remarkable way, using his voice to breathe life into this extraordinary text and making it into an authentic sonata of ambiguous sounds. ${ }^{12}$ In one passage from the page, Themerson mentions that at one of the "Merz poetry recitals" organised by Mesens in London in 1947, two gentlemen from the BBC appeared with the intention of making a recording of the Ursonate. Schwitters began to read his work, and the men left the room halfway through his recitation. Themerson, in contrast, was certainly able to appreciate the significance of the recitation (or perhaps even execution) of this work, and, without any other way of rendering it in the text, he decided to include photographs depicting the shape of the artist's mouth at random moments.

As for Kurt Schwitters on a Time Chart, it is like a real patchwork, which forces the reader to stitch together and join disparate sentences, drawings, various types of font and typographically reproduced writing, diverse icons and red datelines arranged, meridian-like, on the page. The reader's memory and knowledge, with access to the signs scattered on the pages, become something of a techné, a machine almost, as well as a craft or practice of producing the text on Schwitters. The book opens with a diagrammatic and distorted image of the two hemispheres of Earth, with a red meridian line passing through one of them. On it is a red dot marking London on the map of the world, and beneath the picture is the caption: "I met him in 1943, in London," with photographs of Themerson and Schwitters alongside it. This book in

12 I found the recitation of Schwitters's work on the curious record lunapark 0,10 , made by Marc Dachy for Sub Rosa publishers in 1999 
particular can be read as a patchwork, the loosely linked, dispersed elements of which have a unique power to generate additional meanings - on the basis of each of them one can construct an extensive narrative that ploughs deep into the intricacies of the history of the last century (the Victorian era evolked by a photography of the queen, the First and Second World Wars, pictures by Cézanne, Picasso, reproductions of Schwitters's works, a photo of the atom bomb, quotations from the works of Hugo Ball and Richard Huelsenbeck). This is both a collective and individual history, the latter being the point of departure. This patchwork construction gives the reader a multidimensional open text, and from it - owing to the extremely dynamic rhythm - emanates the tremendous force of interlinked meanings deriving from various semantic orders, and thus strongly diversified meanings as well.

What we see here is a unique case of the coexistence of words and images, shifting incessantly. The text composed of these words and images never actually ends (the last page of the book is a mesh of red vertical line-meridians, so the story told by Themerson seems to have no end) and is rearranged without end, with the words and pictures not so much expressing some encrypted code as rather exhibiting the coding work itself. This means that there is no ready, ordered system, as it is the act of generating the system itself which is foregrounded. The patchwork made by Themerson arranges itself into a text with no centre, in which no traditional linearity can be found and in some places it must be read in various directions (literally and metaphorically, as sometimes it is necessary to turn the book various ways to read a given passage), as well as returning to the previous pages, sometimes even making sure that one has read everything.

As much as possible, I have objectively referred to (how many traces here are passed over, invisible, with only partial access to them, or erased, sometimes completely unclear, so there is no access to them at all) the remarkable story of the acquaintance between two artists which inspired Themerson to create his remarkable books about Schwitters.

This story of a strange acquaintance is truly strange, as well as instructive, as it brings Themerson's own ways of reasoning, and his aesthetic choices, a little closer. It is the history of an artist and poet related by a fellow artist and poet, and let us especially emphasise that they were creators of ideas who, only after long years have passed, find their ideas developed by scholars dealing with the philosophy of language, ideas that allow contemporary society to better grasp the reality surrounding it, and they remain a rich source of inspiration for writers and artists all over the world. 